\title{
STUDIES ON HUMAN GROWTH HORMONE. II. THE PHYSIOLOGICAL DISPOSITION AND METABOLIC FATE OF HUMAN GROWTH HORMONE IN MAN *
}

\author{
By MARY L. PARKER, ROBERT D. UTIGER AND WILLIAM H. DAUGHADAY \\ (From the Metabolism Division, Department of Medicine, Washington University School of \\ Medicine, St. Louis, Mo.)
}

(Submitted for publication June 29, 1961 ; accepted October 5, 1961)

The metabolic effects of human growth hormone have received much attention, but little is known regarding the metabolism of the hormone itself in man. Studies of growth hormone metabolism carried out in experimental animals suggest that both bovine growth hormone and human growth hormone have rapid turnovers. Van Dyke, Simpson, Li and Evans (1) and Gemzell, Heijkenskjöld and Ström (2) injected rats with large doses of bovine growth hormone and determined plasma levels of growth hormone by the tibial cartilage width assay. The half-lives of disappearance were 26 and 40 minutes, respectively, in the two studies, and the volume of distribution of the hormone was roughly equivalent to the extracellular fluid space. Isotopic methods have also been applied to the study of growth hormone metabolism. Sonenberg and co-workers (3) injected rats with radioiodinated bovine growth hormone and, although their work was principally concerned with tissue localization, they published a graph depicting the disappearance of radioactivity from plasma after a single intravenous injection. The half-life of disappearance was approximately 25 minutes. In the experiments of Salmon, Utiger, Parker and Reichlin (4), radioiodinated human growth hormone had a half-life of disappearance from plasma of 17 minutes when injected into rabbits.

Only preliminary reports of the disappearance

* Supported by Research Grant A-1526 from the National Institute of Arthritis and Metabolic Diseases, National Institutes of Health, and by an Institutional Grant to Washington University from the American Cancer Society. Clinical studies were carried out on the Washington University-Barnard Hospital Clinical Research Center, under support of Grant OG-12, Division of General Medical Sciences, National Institutes of Health. Presented in part before the 53rd Annual Meeting of the American Society for Clinical Investigation, Atlantic City, N. J., May, 1961. of human growth hormone from serum after injection into human beings have appeared. Gemzell (5) administered the unphysiologically large dose of $50 \mathrm{mg}$ of human growth hormone to normal and hypopituitary subjects by a single intravenous injection. The disappearance from plasma of growth hormone activity as measured by tibial line assay in hypophysectomized rats was said to be slow, with an apparent half-life of 9 hours. A full report of these studies has not yet been published. Read and Bryan (6) have determined serum growth hormone concentrations by a hemagglutination inhibition assay after administration of human growth hormone to hypopituitary patients. When $4 \mathrm{mg}$ of hormone was administered intramuscularly to three patients, the serum concentration rose to a maximum of 100 to 150 $\mathrm{m} \mu \mathrm{g}$ per $\mathrm{ml}$ within the first 4 hours with a gradual return to the preinjection level by 24 hours. Serum levels of human growth hormone were also measured in one patient after the intravenous injection of $4 \mathrm{mg}$. A sustained elevation in the hormone level to $300 \mathrm{~m} \mu \mathrm{g}$ per $\mathrm{ml}$ was noted at 1,4 , and 24 hours after injection, suggesting a halflife of well over 24 hours.

This paper reports the plasma levels of growth hormone measured by a radio-immunoassay after intramuscular and intravenous injection of human growth hormone. The results so obtained have been compared with observations made after intramuscular and intravenous injection of human growth hormone labeled with iodine- $\mathrm{I}^{131}$. On the basis of the experimental findings, preliminary calculations have been made of the distribution and turnover of growth hormone.

\section{METHODS AND MATERIALS}

Experimental subjects. The age, sex, and clinical state of the 17 experimental subjects are listed in Table I. Except for one patient with hypopituitarism and one 
patient with mild hypothyroidism, none had evidence of metabolic disease. The subjects were not restricted in their diet or activities during the study.

Routes of administration and dose. Unlabeled human growth hormone (HGH), was administered in doses of 5 or $10 \mathrm{mg}$ dissolved in isotonic sodium chloride solution. When human growth hormone labeled with $\mathrm{I}^{131}$ (HGH$\mathrm{I}^{131}$ ) was injected intravenously, a dose calculated to contain from 0.2 to $0.003 \mathrm{mg}$ and having a specific activity ranging from 0.03 to $3.4 \mathrm{mc}$ per $\mathrm{mg}$ was given by antecubital vein. When $\mathrm{HGH}-\mathrm{I}^{131}$ was injected intramuscularly, $0.5 \mathrm{ml}$, containing 0.003 to $0.005 \mathrm{mg}$, was given with a $5 / 8$-inch needle into the deltoid muscle. Thyroid uptake of $\mathrm{I}^{131}$ was suppressed by the oral administration of potassium iodide.

Collection of specimens. Blood was drawn from the antecubital vein in a heparinized syringe. The plasma was separated promptly and stored at $-14^{\circ} \mathrm{C}$ until extracted or counted. Urine was collected at intervals for 24 hours after the administration of $\mathrm{HGH}-\mathrm{I}^{131}$.

Iodination of human growth hormone for injection. HGH made by the Raben process (7) was iodinated by a modification of the distillation technique of Staub, Springs and Elrick (8). In the present experiments HGH-I ${ }^{131}$ was stabilized during dialysis with human serum albumin. The final product contained a calculated amount of iodine equivalent to 1 to 2 atoms of iodine per molecule of growth hormone. Cold 5 per cent trichloroacetic acid (TCA) precipitated 97 per cent or more of the radioactivity of the final product; an excess of specific antibody against $\mathrm{HGH}$ bound 84 to 86 per cent of the radioactivity of the same product. The migration of radioactivity during starch block electrophoresis corresponded to that of unlabeled $\mathrm{HGH}$ as determined by immunoassay. The iodinated hormone was passed through a Seitz filter and its sterility was confirmed by culture before use.

Immunoassay for human growth hormone. HGH was extracted from plasma and assayed by a specific radioimmunoassay (9). In this assay the extracted HGH competes with $\mathrm{HGH}-\mathrm{I}^{131}$ for binding by rabbit anti-HGH antibodies. Free $\mathrm{HGH}-\mathrm{I}^{131}$ is separated from $\mathrm{HGH}-\mathrm{I}^{131}$ bound to rabbit antibody by precipitation of rabbit $\gamma$-globulins with an excess of goat antirabbit $\gamma$-globulin (antiRGG) serum. The addition of HGH inhibits the precipitation of $\mathrm{HGH}-\mathrm{I}^{131}$ and the increase in nonprecipitated HGH-I ${ }^{131}$ (supernatant HGH-I ${ }^{131}$ ) is directly proportional to the logarithm of the HGH concentration in each tube. In an assay run, a standard curve was defined with 8 concentrations of $\mathrm{HGH}$ from 3 to $400 \mathrm{~m} \mu \mathrm{g}$. The concentration of $\mathrm{HGH}$ in plasma extracts was determined at one or two dilutions.

Assay of radioactivity. Plasma and urine samples were analyzed for total radioactivity and for radioactivity remaining after precipitation with 5 per cent TCA; the TCA-precipitable radioactivity was determined by difference. Bovine serum albumin in a final concentration of 0.5 per cent was added to urine samples prior to the precipitation with TCA. Immunoprecipitation of plasma samples from two of the subjects, (M.P., M.R.) was also carried out with an excess of rabbit anti-HGH serum and anti-RGG serum, permitting a comparison of the TCAprecipitable and the immunologically precipitable radioactivity.

All plasma and urine samples were counted in a uniform volume in a well-type scintillation counter. For a given experiment all plasma samples, urine samples, and suitable dilutions of the injected material were counted together so that a correction for radioactive decay was not necessary.

Radioactivity remaining at the site of the intramuscular injection was determined with a collimated scintillation detector at a distance of $8 \mathrm{~cm}$. Counts over a comparable area of the contralateral extremity were made and subtracted from the counts over the site of injection to correct for circulating $\mathrm{HGH}-\mathrm{I}^{131}$.

\section{RESULTS}

Intravenously administered hormone. The disappearance of HGH from plasma was measured in five subjects after intravenous administration. There was a rapid fall from the high initial level, reaching the preinjection level by 3 hours in the subjects given $5 \mathrm{mg}$ and by 5 hours in the subjects given $10 \mathrm{mg}$ (Figure 1). When the logarithm of the plasma $\mathrm{HGH}$ concentration was plotted against time, the disappearance curve could be described as a straight line over the time interval of 10 to 100 minutes (Figure 2). The

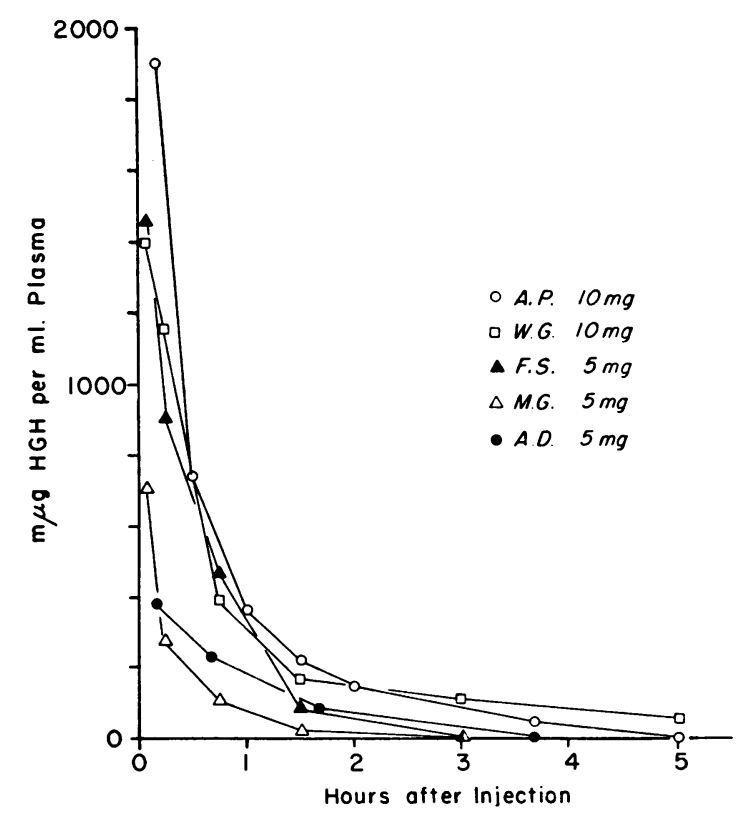

Fig. 1. Plasma levels of human growth hormone AFTER INTRAVENOUS ADMINISTRATION OF A 5 OR 10 MG DOSE. 


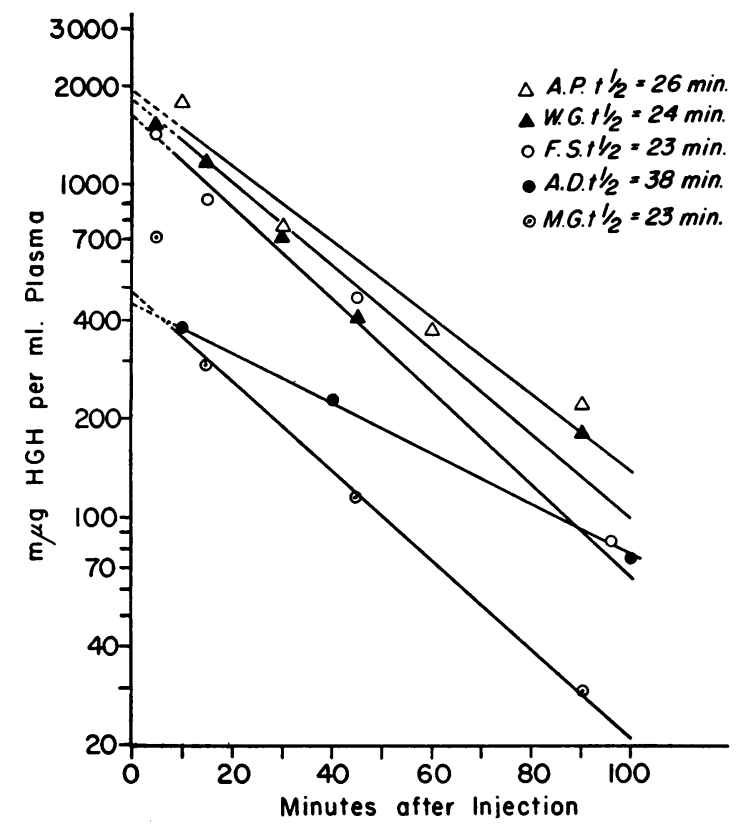

Fig. 2. Disappearance OF UNLABEled human GROWTH HORMONE FROM PLASMA AFTER INTRAVENOUS ADMINISTRATION. The slopes have been calculated using values observed between 10 and 100 minutes.

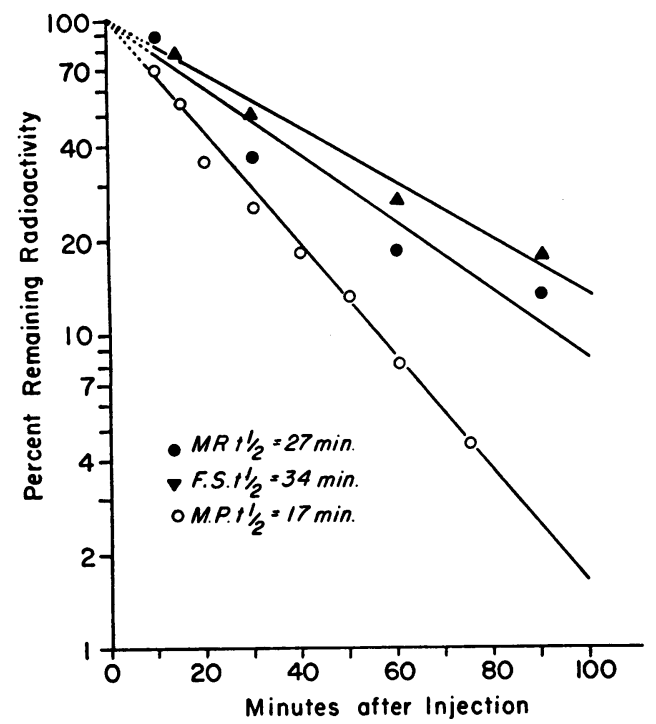

Fig. 3. Disappearance of PRECIPITABle RAdioactivity FROM PLASMA AFTER INTRAVENOUS ADMINISTRATION OF I ${ }^{181}$-LABELED HUMAN GROWTH HORMONE. TCA-precipitable radioactivity at zero time was determined by extrapolation of calculated slope for TCA-precipitable radioactivity from 10 to 100 minutes. This value was then plotted as 100 per cent. F.S. received $200 \mu \mathrm{g}$ with a specific activity of $30 \mu \mathrm{c}$ per mg. M.P. received $200 \mu \mathrm{g}$ with a specific activity of $430 \mu \mathrm{c}$ per mg. M.R. received $3 \mu \mathrm{g}$ with specific activity of $3.4 \mathrm{mc}$ per $\mathrm{mg}$. half-time of disappearance was found to vary between 23 to 38 minutes with a mean of 27 minutes. A slower component of disappearance was evident after this period only in the case of a subject who received $10 \mathrm{mg}$ of $\mathrm{HGH}$.

After intravenous injection of $\mathrm{HGH}-\mathrm{I}^{131}$, the plasma TCA-precipitable radioactivity also decreased rapidly. The time course of disappearance during the period from 10 to 100 minutes was similar to that observed with $\mathrm{HGH}$, having a half-life of 17,27 , and 34 minutes, respectively (Figure 3 ). TCA-soluble radioactivity appeared promptly in the plasma, and by 30 minutes ac-

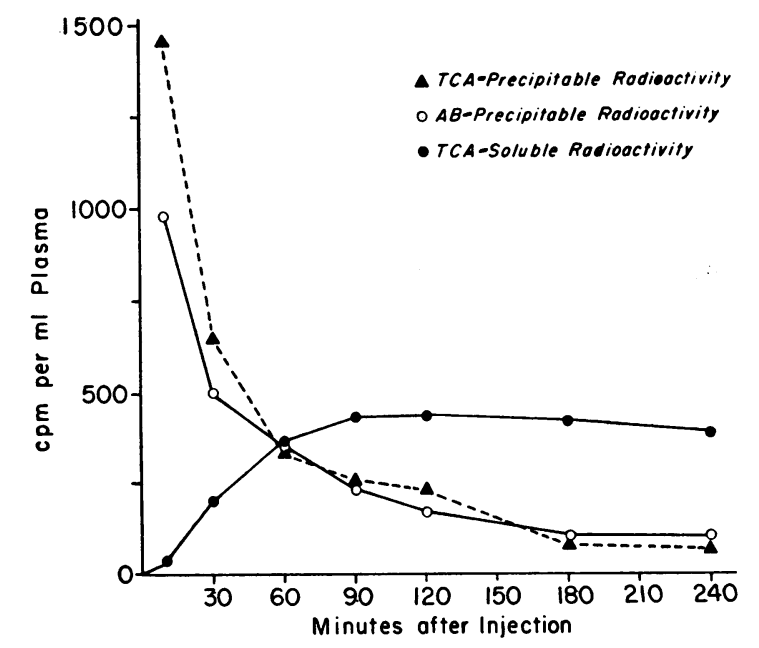

Fig. 4. A comparison of the PRECIPItability of RADIOACTIVITY IN PLASMA BY TRICHLOROACETIC ACID AND BY ANTI-HGH ANTIBODY AFTER INTRAVENOUS ADMINIStration of $3 \mu \mathrm{G}$ of HGH-I ${ }^{131}$ to Patient M.R. This preparation was 97.6 per cent TCA-precipitable and 84 per cent antibody-precipitable.

counted for 23 per cent or more of the total plasma radioactivity. In two experiments, the TCAprecipitable radioactivity, as well as the immunoprecipitable radioactivity was determined. The results obtained with the two methods were in good agreement after the first 30 minutes (Figure 4).

Radioactivity was also measured in the urine after intramuscular injection of HGH-I ${ }^{131}$. Virtually none of the radioactivity could be precipitated by TCA. By 24 hours, 85 per cent or more of the administered radioactivity was recovered in the urine.

The distribution of radioactivity between extracellular TCA-precipitable, extracellular TCA- 
soluble, and urine components in the observations on M.R. has been calculated (Figure 5). The sizable fraction of radioactivity which could not be assigned to these components was assumed to be associated with tissues either as the intact growth hormone molecule or as its degraded components.

Intramuscularly administered hormone. Plasma growth hormone levels were measured in eight subjects after intramuscular injection of $\mathrm{HGH}$ (Figure 6). There was considerable variation in the maximal plasma hormone level attained and in the shape of the curves. More consistent results appeared to follow deltoid rather than gluteal injection. As this variability was not ob-

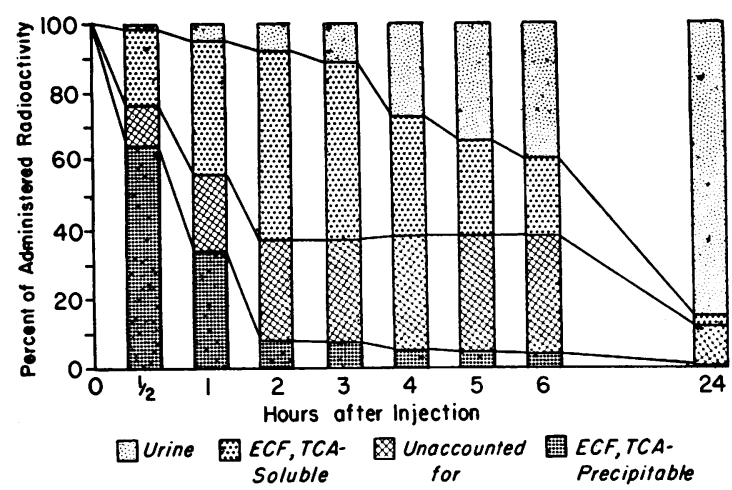

Fig. 5. Fate of Isi after intravenous administraTION OF LABELED HUMAN GROWTH HORMONE TO M.R. Calculations are based on data presented in Figure 4. Extracellular fluid volume was calculated on the basis of 20 per cent of body weight. The TC,A-precipitable component was capable of reacting with anti-HGH antibodies.

served after intravenous injection, uneven absorption from the intramuscular depot may have occurred.

The kinetics of absorption of HGH-I ${ }^{131}$ after intramuscular injection have been measured in three subjects. Radioactivity disappeared from the injection site progressively; the calculated half-lives of disappearance were 95,110 , and 125 minutes for the three experiments (Figure 7). The earliest radioactivity which appeared in the plasma was largely TCA-precipitable (Figure 8 ). Thirty minutes after injection, 70 per cent of the plasma radioactivity was TCA-precipitable, but with time the fraction of precipitable $\mathrm{HGH}-\mathrm{I}^{131}$ decreased so that by 6 hours, TCA-precipitable HGH-I ${ }^{131}$ was 10 per cent or less. By 24 hours,

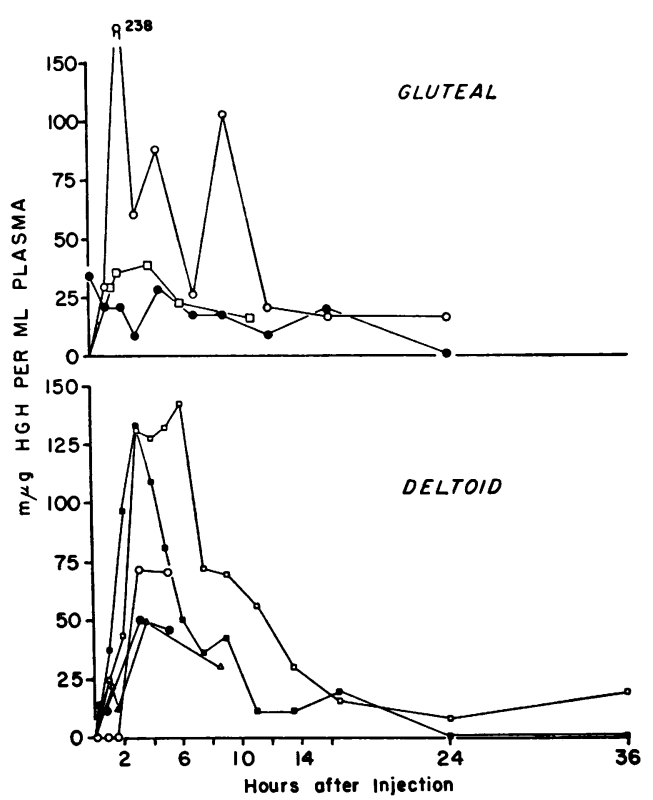

Fig. 6. Plasma levels of human growth hormone AFTER INTRAMUSCULAR ADMINISTRATION OF 10 MG HUMAN GROWTH HORMONE.

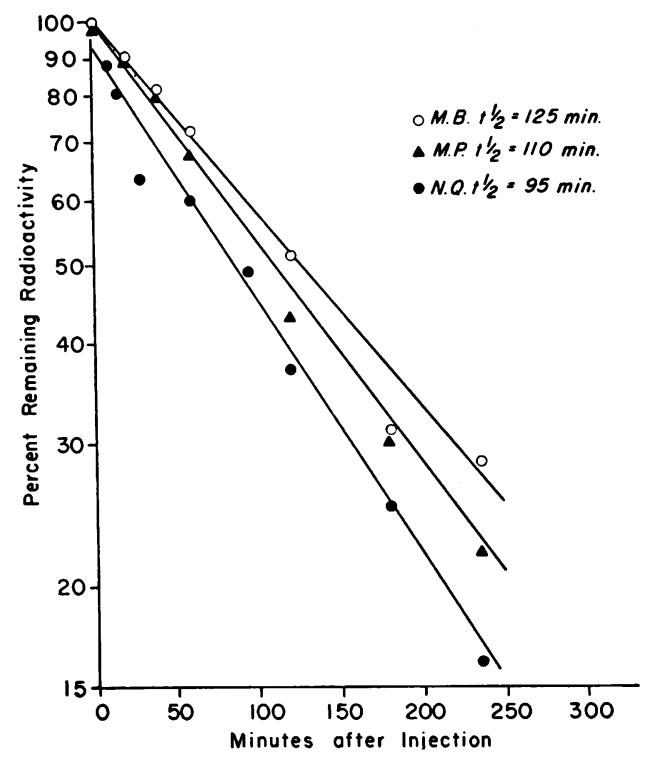

Fig. 7. DisAppearance of RAdioactivity From the SITE OF INJECTION AFTER INTRAMUSCULAR ADMINISTRATION OF I ${ }^{131}$-LABELED HUMAN GROWTH HORMONE. Counts for the 0 to 1 minute interval were taken as 100 per cent of radioactivity. The slopes have been calculated using all values observed during the first 4 hours. M.B. and M.P. received $5 \mu \mathrm{g}$ with a specific activity of $1.2 \mathrm{mc}$ per $\mathrm{mg}$. N.Q. received $3 \mu \mathrm{g}$ with a specific activity of $3.4 \mathrm{mc}$ per $\mathrm{mg}$. 


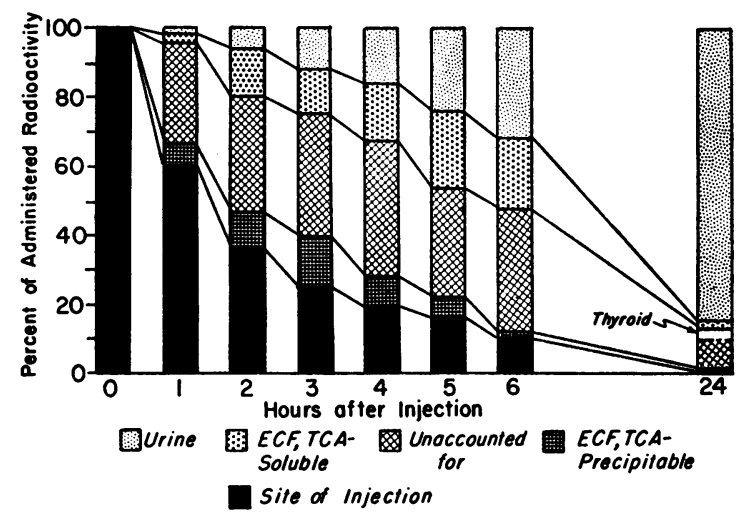

Fig. 8. FAte of I I81 AFter intramuscular AdMinisTRATION OF $3 \mu$ G LABELED HUMAN GROWTH HORMONE TO N.Q. Values for radioactivity at the site of injection were based on the 0 to 1 minute interval; this value was taken as 100 per cent of administered radioactivity, as measured by a collimated scintillation detector. Extracellular fluid volume was calculated on the basis of 20 per cent of body weight.

85 per cent or more of the administered radioactivity was recovered in the urine.

\section{DISCUSSION}

The growing recognition of species differences in protein hormone structure makes it unwise to assume that the metabolism of a foreign hormone is a true indication of the metabolism of the homologous hormone. A noteworthy feature of these observations is that the metabolism of a hormone has been studied in the same species from which it was extracted.

These observations have been based on the premise that human growth hormone as extracted by the Raben procedure is the same molecular species as circulating growth hormone. The possibility exists that the extreme conditions of temperature, $\mathrm{pH}$, and exposure to organic solvents used in the Raben extraction procedure could induce structural changes in the hormone. There is, however, no direct evidence that this is the case. The evidence is clear that antibodies evoked by the Raben human growth hormone react with simple extracts of whole pituitary (6) and with components of normal and acromegalic plasma $(6,10)$.

Preliminary estimates of the volume of distribution of growth hormone are possible. As already indicated, the disappearance of growth hormone from the plasma after intravenous injection conforms to a single exponential function from 10 to 100 minutes. The values obtained at 5 minutes fell above this line suggesting incomplete mixing.

TABLE I

Clinical data on subjects

\begin{tabular}{|c|c|c|c|c|c|c|c|}
\hline \multirow[b]{2}{*}{ Subject } & \multirow[b]{2}{*}{ Age } & \multirow[b]{2}{*}{$\operatorname{Sex}$} & \multirow[b]{2}{*}{ Wt } & \multirow[b]{2}{*}{ Clinical status } & \multicolumn{3}{|c|}{ Growth hormone administration } \\
\hline & & & & & Hormone & Route & Dose \\
\hline $\begin{array}{l}\text { W.G. } \\
\text { A.P. } \\
\text { A.D. } \\
\text { M.G. }\end{array}$ & $\begin{array}{l}y r s \\
33 \\
24 \\
32 \\
26\end{array}$ & $\begin{array}{l}\mathrm{F} \\
\mathrm{M} \\
\mathrm{M} \\
\mathrm{F}\end{array}$ & $\begin{array}{l}k g \\
59 \\
64 \\
59 \\
73\end{array}$ & $\begin{array}{l}\text { Normal } \\
\text { Normal } \\
\text { Panhypopituitarism } \\
\text { Normal }\end{array}$ & $\begin{array}{l}\text { HGH } \\
\text { HGH } \\
\text { HGH } \\
\text { HGH }\end{array}$ & $\begin{array}{l}\text { i.v. } \\
\text { i.v. } \\
\text { i.v. } \\
\text { i.v. }\end{array}$ & $\begin{array}{r}m g \\
10 \\
10 \\
5 \\
5\end{array}$ \\
\hline F.S. & 40 & $\mathbf{F}$ & 82 & Mild hypopituitarism & $\begin{array}{l}\text { HGH } \\
\text { HGH } \\
\text { HGH-I }{ }^{131}\end{array}$ & $\begin{array}{l}\text { i.v. } \\
\text { i.m. } \\
\text { i.v. }\end{array}$ & $\begin{array}{l}5 \\
10 \\
0.2(30 \mu c / m g)\end{array}$ \\
\hline $\begin{array}{l}\text { M.P. } \\
\text { M.R. }\end{array}$ & $\begin{array}{l}48 \\
30\end{array}$ & $\begin{array}{l}F \\
F\end{array}$ & $\begin{array}{l}46 \\
52\end{array}$ & $\begin{array}{l}\text { Metastatic breast cancer } \\
\text { Normal }\end{array}$ & $\begin{array}{l}\text { HGH-I }{ }^{131} \\
\text { HGH-I }\end{array}$ & $\begin{array}{l}\text { i.v. } \\
\text { i.v. }\end{array}$ & $\begin{array}{l}0.2(430 \mu \mathrm{c} / \mathrm{mg}) \\
0.003(3.4 \mathrm{mc} / \mathrm{mg})\end{array}$ \\
\hline $\begin{array}{l}\text { D.S. } \\
\text { M.B. } \\
\text { C.M. } \\
\text { J.W. } \\
\text { A.S. } \\
\text { G.S. } \\
\text { D.S. }\end{array}$ & $\begin{array}{l}15 \\
23 \\
24 \\
25 \\
25 \\
25 \\
26\end{array}$ & $\begin{array}{l}\mathrm{F} \\
\mathrm{M} \\
\mathrm{F} \\
\mathrm{F} \\
\mathrm{M} \\
\mathrm{M} \\
\mathrm{M}\end{array}$ & $\begin{array}{l}39 \\
90 \\
71 \\
61 \\
76 \\
75 \\
72\end{array}$ & $\begin{array}{l}\text { Normal } \\
\text { Normal } \\
\text { Normal } \\
\text { Normal } \\
\text { Normal } \\
\text { Normal } \\
\text { Normal }\end{array}$ & $\begin{array}{l}\text { HGH } \\
\text { HGH } \\
\text { HGH } \\
\text { HGH } \\
\text { HGH } \\
\text { HGH } \\
\text { HGH }\end{array}$ & $\begin{array}{l}\text { i.m. } \\
\text { i.m. } \\
\text { i.m. } \\
\text { i.m. } \\
\text { i.m. } \\
\text { i.m. } \\
\text { i.m. }\end{array}$ & $\begin{array}{l}10 \\
10 \\
10 \\
10 \\
10 \\
10 \\
10\end{array}$ \\
\hline $\begin{array}{l}\text { M.B. } \\
\text { N.Q. } \\
\text { M.P. }\end{array}$ & $\begin{array}{l}19 \\
25 \\
36\end{array}$ & $\begin{array}{l}F \\
F \\
F\end{array}$ & $\begin{array}{l}50 \\
53 \\
59\end{array}$ & $\begin{array}{l}\text { Normal } \\
\text { Normal } \\
\text { Normal }\end{array}$ & $\begin{array}{l}\text { HGH-I'131 } \\
\text { HGH-I } \\
\text { HGH-I }\end{array}$ & $\begin{array}{l}\text { i.m. } \\
\text { i.m. } \\
\text { i.m. }\end{array}$ & $\begin{array}{l}0.005(1.2 \mathrm{mc} / \mathrm{mg}) \\
0.003(3.4 \mathrm{mc} / \mathrm{mg}) \\
0.005(1.2 \mathrm{mc} / \mathrm{mg})\end{array}$ \\
\hline
\end{tabular}


The initial growth hormone concentration obtained by extrapolating the disappearance curve to zero permitted a calculation of the mean volume of distribution of 15 per cent of body weight (range, 5 to 20 per cent). These results suggest that growth hormone is distributed promptly throughout the extracellular compartment.

The present results also permit certain preliminary calculations of the secretory rate of growth hormone. The fractional turnover rate can be determined from the expression $\mathrm{K}=0.69$ / $t_{1}$ (11). If the half-life is taken to be 27 minutes, $\mathrm{K}=2.6$ per cent per minute. We have published observations in a companion paper which indicate that the normal human growth hormone level is only about $10 \mathrm{~m} \mu \mathrm{g}$ per $\mathrm{ml}$ of plasma (9). This would mean that a $70 \mathrm{~kg}$ man would have about $140 \mu \mathrm{g}$ of hormone in the extracellular fluid. If 2.6 per cent of this pool were turned over every minute, the daily production would be about 5 $\mathrm{mg}$. It is interesting that this amount of hormone is sufficient to produce a restoration of normal growth in hypopituitary dwarfs $(12,13)$ and is approximately the content of growth hormone in a single pituitary $(14,15)$.

Caution is warranted in interpreting the results obtained with radioiodinated growth hormone. Although the disappearance of the iodinated hormone from the plasma corresponded to that of the unlabeled hormone, the metabolism of the iodinated hormone may not truly represent the metabolism of endogenous hormone. The experience obtained with metabolic studies using radioiodinated human albumin indicate that subtle damage to the molecule may greatly alter its metabolic fate $(16,17)$. In comparison to human serum albumin, growth hormone has proved to be very easily damaged by iodination. All that can be said about our preparations of labeled hormone is that their immunoreactivity has been largely preserved and the concentration of inorganic iodine was low.

It is interesting to note that within a very short period of time after intravenous administration of labeled human growth hormone the initial discrepancy between the TCA-precipitable radioactivity and the specific antibody-precipitable radioactivity disappears. This observation suggests that the body may be clearing the immunologically unreactive growth hormone (presumably
I 131-labeled degradation units) more rapidly than the immunoreactive molecules in a manner similar to that described for human serum proteins (18).

In the present study the disappearance of radioactivity from the injection site has been equated with growth hormone absorption. It is realized that labeled breakdown products as well as free radioactive iodine itself may be formed as a result of local degradation of the hormone. It is unlikely, however, that these products would remain at the site of injection. $\mathrm{NaI}^{131}$ has been shown to disappear rapidly from the subcutaneous tissues with a half-life of disappearance of 20 minutes (19), and a similarly rapid disappearance for peptide fragments would be expected. Local degradation would therefore be expected to increase the rate of disappearance from the muscle. Studies on insulin- $\mathrm{I}^{131}$ absorption in normal subjects show a half-life of disappearance of $88 \mathrm{~min}$ utes (19). This value is of the same order of magnitude as that for growth hormone. By contrast, $\mathrm{I}^{131}$-labeled albumin has been shown to have a half-life of disappearance from the injection site of 13 hours (19).

The possible effects of trace contaminants in the original growth hormone preparation on the disappearance of plasma radioactivity deserve comment. Labeling of albumin, globulin, or fibrinogen, all known to have half-lives of disappearance from the plasma of many days (20), would prolong the half-time of disappearance of radioactivity from the plasma. ACTH has been shown to have a biological half-life of only a few minutes (21) ; therefore, labeling this hormone would lead to a faster rate of clearance of radioactivity. Less is known concerning the turnover of other pituitary hormones. In view of the results of electrophoresis of our labeled hormone (9), it is felt that these contaminants do not contribute significantly to the total radioactivity.

It would be premature to make specific statements regarding the fate of human growth hormone in the tissues; however, the persistence of a fraction of label outside the extracellular fluid suggests that the over-all half-life of disappearance of human growth hormone from the tissues is longer than that from the extracellular fluid (Figures 5 and 8). Elsewhere, two of us (RU and MP) in collaboration with Salmon and Reichlin (4) have demonstrated the persistence of TCA- 
precipitable radioactivity in neurohypophysis, liver, kidney, and muscle, 90 minutes after the injection of rabbits with labeled human growth hormone. Precipitation of radioactivity from liver and kidney by specific antigrowth hormone immune serum provided additional evidence of the probable persistence of the hormone in the tissues.

\section{SUMMARY}

The successful iodination of human growth hormone has made possible the study of the metabolism of this hormone in man, both by a radioimmunoassay of unlabeled hormone and by measurement of the labeled protein in plasma.

After intravenous injection of human growth hormone, plasma levels fell exponentially with an average half-life of 27 minutes, a fractional turnover rate of 2.6 per cent per minute, and an estimated turnover of $5 \mathrm{mg}$ per day.

After intramuscular injection of $\mathrm{I}^{131}$-labeled human growth hormone, there was a fall in the radioactivity at the site of injection, with a halflife of 110 minutes. Injection of unlabeled human growth hormone was followed by a slow rise in plasma levels, a flattening at 3 to 6 hours, and a slower return to the preinjection level within 18 to 24 hours.

\section{ACKNOWLEDGMENT}

The authors wish to thank Dr. Joseph D. Fisher of Armour Laboratories for his contributions to this project.

\section{REFERENCES}

1. Van Dyke, D. C., Simpson, M. E., Li, C. H., and Evans, H. M. Survival in the circulation of the growth and adrenocorticotrophic hormones as evidenced by parabiosis. Amer. J. Physiol. 1950, 163, 297.

2. Gemzell, C. A., Heijkenskjöld, F., and Ström, L. Rate of disappearance of growth hormone from the plasma of rats after a single intravenous injection. Acta endocr. (Kbh.) 1955, 19, 181.

3. Sonenberg, M., Money, W. L., Dorans, J. F., Lucas, V., and Bourque, L. The distribution of radioactivity in the tissues of the rat after the administration of radioactive growth hormone preparations. Endocrinology 1954, 55, 709.

4. Salmon, S., Utiger, R. D., Parker, M. L., and Reichlin, S. The fate of $I^{131}$ labeled human growth hormone in the rabbit. Endocrinology. In press.

5. Gemzell, C. A. Discussion in Ciba Foundation Colloquia on Endocrinology, G. E. W. Wolstenholme and C. M. O'Connor, Eds. Boston, Little, Brown, 1959, vol. 13, p. 87.

6. Read, C. H., and Bryan, G. T. The immunological assay of human growth hormone. Recent Progr. Hormone Res. 1960, 16, 187.

7. Raben, M. S. Preparation of growth hormone from pituitaries of man and monkey. Science 1957, 125, 883.

8. Staub, A., Springs, V., and Elrick, H. An improved technique for labelling proteins with $\mathrm{I}^{131}$. Int. J. appl. Radiat. 1957, 2, 59.

9. Utiger, R. D., Parker, M. L., and Daughaday, W. H. Studies on human growth hormone. I. A radioimmunoassay for human growth hormone. J. clin. Invest. 1962, 41, 254.

10. Hartog, M., and Fraser, R. The immunological assay of growth hormone in human serum. J. Endocr. 1961, 22, 101.

11. Zilversmit, D. B. The design and analysis of isotope experiments. Amer. J. Med. 1960, 29, 832.

12. Bergenstal, D. M., and Lipsett, M. B. Metabolic effect of human growth hormone and growth hormone of other species in man. J. clin. Endocr. 1960, 20, 1427.

13. Henneman, P. H., Forbes, A. P., Moldawer, M., Dempsey, E. F., and Carroll, E. L. Effects of human growth hormone in man. J. clin. Invest. 1960, $39,1223$.

14. Li, C. H. Studies on human pituitary growth and gonadotropic hormones in Ciba Foundation Colloquia on Endocrinology, G. E. W. Wolstenholme and C. M. O'Connor, Eds. Boston, Little, Brown, 1959, vol. 13 , p. 54.

15. Gemzell, C. A., and Heijkenskjöld, F. Growth hormone content in human pituitaries. Endocrinology 1956, 59, 681.

16. Steinfeld, J. L., Greene, F. E., Tabern, D. L., Paton, R. R., and Flick, A. L. Degradation of iodinated human serum albumin prepared by various procedures. J. Lab. clin. Med. 1958, 51, 756.

17. Berson, S. A., Yalow, R. S., Schrieber, S. S., and Post, J. Tracer experiments with $I^{131}$ labeled human serum albumin: Distribution and degradation studies. J. clin. Invest. 1953, 32, 746.

18. McFarlane, A. S. Labelling of plasma proteins with radioactive iodine. Biochem. J. 1956, 62, 135.

19. Moore, E. W., Mitchell, M. L., and Chalmers, J. C. Variability in absorption of insulin- ${ }^{131}$ in normal and diabetic subjects after subcutaneous and intramuscular injection. J. clin. Invest. 1959, 38, 1222.

20. Anker, H. S. The biosynthesis of plasma proteins in The Plasma Proteins, F. W. Putnam, Ed. New York, Academic Press, 1960, vol. II, p. 267.

21. Syndor, K. L., and Sayer, G. Biologic half-life of endogenous ACTH. Proc. Soc. exp. Biol. (N. Y.) 1953, 83, 729. 